\title{
The Verbal and Nonverbal Communicative Abilities of Pre-Adolescent Stutterers
}

\author{
Monica Bucher BA (Sp. \& H. Therapy) (Witwatersrand) \\ Transvaal Education Department \\ Psychological and guidance services \\ Melissa Bortz BA (Sp. \& H. Therapy) (Witwatersrand) \\ Department of Speech Therapy \& Audiology \\ Coronation Hospital, Johannesburg \\ Denise Anderson BA (Sp. \& H. Therapy) (Witwatersrand) \\ Department of Speech Pathology and Audiology \\ University of the Witwatersrand, Johannesburg
}

\begin{abstract}
The aim of this study was to investigate and describe some aspects of the verbal and nonverbal communicative competence of six pre-adolescent stutterers. A communication inventory was used to assess competence in relation to four communication functions and two contexts. The sample obtained was transcribed and analyzed in terms of nonverbal and verbal behaviours, including morpheme length and paralinguistic features. The results indicated that the subjects were, on average, incompetent in all areas of communication. Correlations were made to stuttering frequency and attitudes to stuttering and sensitivity to communication. Diagnostic and therapeutic implications are discussed.
\end{abstract}

\section{UITTREKSEL}

Die doel van die studie was om aspekte van die verbale en nie verbale kommunikasie vermoë van ses pre-adolessente hakkelaars na te vors en te beskryf. ' $n$ Kommunikasie inventaris is gebruik om die vermoë in verband met vier kommunikasie funksies en twee kontekste te bepaal. Die materiaal is neergeskryf en ontleed in verband met die verbale en nie verbale opdragte, ook met morfeem lengte en parataalkunde kenmerke insluit. Die resultate toon dat die proefpersone gemiddeld nie in staat was tot al die aspekte van kommunikasie nie. Korrelasies is gemaak tussen hakkel frekwensies en houding en sensitiwiteit vir kommunikasie. Diagnostiese en terapeutiese verwysings is bespreek.

Shames and Florance (1980) report on a stutterer who said, "I recall many times that I had been in restaurants and wanted to order something of my choice and anticipated stuttering and would select something else from the menu because it was easier to say that word at that moment" (p. 4). This reveals a marked communication impairment in that it distorts the stutterer's ability to "share" in a social manner, which is what the very word "communication" means (Cherry 1978; Wood 1981).

Communication, according to Myers and Myers (1976) is at the core of our humanness. Alant (1979) feels that it expresses social reality. Communication may take place by verbal or nonverbal means. Verbal communication is defined by Wiig and Semel (1976) as "the exchange of ideas, intentions, or information by speakers using a common language" (p. 323). Abercrombie's (1968) statement that man speaks with his vocal organs, but converses with his whole body, indicates, however, that the mechanical act of speech is only meaningful in its interaction with nonverbal communication. Communication does not simply mean "fluent verbal communication" or "adequate nonverbal communication", but rather, effective verbal and nonverbal communication in particular situations (Alant 1979).
Recently the focus of language research has been expanded to include language usage in social contexts. Much current research in speech pathology is conducted within a pragmatic functional framework. There is however, a dearth of literature on stuttering within this paradigm.

Dalton and Hardcastle (1977) feel that the major effect of stuttering on communication may perhaps be the sheer absorption that stutterers have in their speech problem. This possibly results in little opportunity to develop adequate communication skills, leading to unspontaneous, inappropriate and insensitive use of language. As Barbara (1972) points out, the stutterer's immediate reaction is usually "What have I said? Was it clear? Were they able to understand me?" Nonverbal communication would express this fear to the listener as it is an accurate and spontaneous transmitter of communicating emotions and conveying information about the person (Argyle 1975). Luper and Mulder (1964) describe the most sévere communicative impairment of the stutterer as that in which the stutterer refuses to talk for fear of stuttering. Stuttering interferes considerably with communication.

Muma (1978) states that by the pre-adolescent stage, pragmatic skills should have been acquired. Features of communica- 
tion that children should be familiar with and use by the middle of primary school, include a fluid flow of initiating and responding to ideas, and a simultaneous use of verbal and non verbal means within an interpersonal framework of communication. As regards the latter, it is interesting to note that stuttering has been described as an interpersonal disorder by both Sheehan (1968) and Van Riper (1978).

Therefore it is important to investigate the pre-adolescent stutterer's use of communication. The present study aims to describe some aspects of the verbal and nonverbal communication performance of a group of pre-adolescent stutterers in order to determine whether they demonstrate inadequate or delayed social- verbal communication skills; and whether stuttering behaviour, attitudes to stuttering and sensitivity to communication are related to communicative competence.

\section{METHODOLOGY}

\section{SUBJECTS (Ss)}

Six male pre-adolescent stutterers were used. This represents the smallest sample size possible for non-parametric withingroup studies (Saling 1983).

\section{DESCRIPTION OF SUBJECTS}

The subjects were phase III or IV stutterers (Bloodstein 1969) within the nine to ten year old age range. None of the subjects had received previous communication skills training. All were monolingual English speakers.

\section{MATERIALS}

\section{Communication Inventory:}

The Let's Talk Inventory for Adolescents (Wiig 1982) was used to assess selective aspects of social-verbal communicative competence of subjects in terms of four communication functions, - ritualising, informing, controlling and feeling, in relation to two contexts - peer and adult.

\section{Attitude to stuttering:}

The Ílva Scale (Johnson, Darley and Spriestersbach 1963) was used for this purpose.

\section{Sensitivity to Communication:}

Alant's Personal and Social Sensitivity Scales (1979) were used to assess the subjects' sensitivity to communication.

\section{PROCEDURE}

The Ss were assessed individually in the same sound treated room with the same seating arrangements. A video recorder was used to ensure that all Ss's responses were accurately recorded for later analysis. The video equipment (National VHS) was placed on the other side of a one-way mirror to make the interaction as natural as possible. Testing conditions were kept constant to ensure that the environment did not affect subject-examiner interactions.

The Attitude to Stuttering and Sensitivity to Communication Scales were administered after the Communication Inventory, so as to ensure no affect on communication behaviour. The data obtained from the Communication Inventory was rated by two speech pathologists in terms of a) verbal and b) nonverbal behaviours. The latter rating is an extension of Wiig's original procedure, and was devised by the writers.

\section{a) Verbal communication analysis}

The verbal behaviours, including paralinguistic features, a morpheme count, communicative competence and related stuttering symptomatology were analyzed in the following way:

\section{Paralinguistic features:}

These were assessed by one of the writers (E) and an independent rater $(R)$ for each $S$ along eight parameters, according to a four point rating scale: 1 - poor; 2 - fair; 3 - adequate; 4 - good. The parameters included rhythm, pitch, intonation, intensity, stress, rate, pausing and embolophrasia.

\section{Morpheme analysis:}

The segments were scored to reflect the mean length of utterance (MLU) in morphemes (Wiig 1982), for the functions and contexts. This score reflects "syntactic-semantic" complexity. As Wiig (1982) pointed out, length does not always reflect verbosity, but may reflect word-finding efforts, circumlocutions, and topical discontinuity. These factors are often very prevalent in stutterers' communication.

\section{Communication competence:}

Competence was scored as a factor of intent (functions) and register (contexts), and related to the norms established by Wiig (1982) and compared as percentages. Speech act association scores were also computed to assess the Ss' receptive communicative competence.

\section{Related verbal stuttering behaviours:}

Stuttering behaviours were analyzed in terms of frequency and severity according to a four-point rating scale based upon Johnson et al. (1963). The $\mathrm{E}$ and $\mathrm{R}$ independently rated the scores for each $S$ on each item of the inventory, according to the following:

0 - no evidence of verbal stuttering behaviour.

1 - mild stuttering behaviour, but not interfering with communication.

2 - moderate stuttering behaviour, consisting of a single severe symptom or two mild examples, thus interfering somewhat with verbal communication.

3 - severe stuttering behaviour characterized by two or more examples of severe stuttering, interrupting the smooth flow of verbal communication.

\section{b) Nonverbal communication analysis}

The writers devised a nonverbal communication analysis that borrowed from several researchers (Argyle 1972; Friesen et al. 1979; Johnson et al. 1963; Knapp 1978; Ling and Ling 1974). Eight movements (see Table 1) formed the data-base and were rated according to the following categories by two raters:

(i) Nonverbal stuttering behaviour (secondary stuttering).

(ii) Nonverbal behaviour distracting from communication.

(iii) Nonverbal behaviour complementing communication.

The rating consisted of marking down the presence of a movement in the sequence in which it occurred in the "speech act" or "moment" of stuttering" that is, while listening to the stimuli and before, during and after speaking (Bales 1960; Van Riper 1973 and 1978). This would determine how stuttering was related to nonverbal communication and which behaviours detracted from or complemented communication. The speech act or "single interaction" was defined as the "smallest discriminable seg- 
Table 1 Movements forming the basis for analysis

\begin{tabular}{|c|c|}
\hline BEHAVIOUR & \multirow{2}{*}{$\begin{array}{l}\text { DESCRIPTION OF MOVEMENT } \\
\text { These were described as deviations of the head from a midline position, the face facing forward. }\end{array}$} \\
\hline Head movements & \\
\hline Gaze & Direction of gaze was considered as looking at partner, looking down or up, or to the side, or at the stimuli. \\
\hline Facial expression & $\begin{array}{l}\text { This included facial configurations which displayed affect. Facial extremities were defined as scalp, ears } \\
\text { and temples. }\end{array}$ \\
\hline Posture & $\begin{array}{l}\text { This included any change in general posture as well as varying positions in the trunk and shoulders and } \\
\text { lower extremities. It was also the general category under which illustrators and manipulators were considered. }\end{array}$ \\
\hline Illustrators and gestures & $\begin{array}{l}\text { These were movements which accompanied speech and illustrated what was being said verbally. They may } \\
\text { have been present in all parts of the body. }\end{array}$ \\
\hline Shrug & This category was defined by the writers and involved a more subtle shoulder movement accompanying speech. \\
\hline Manipulators & $\begin{array}{l}\text { These were either (i) self manipulators which included movements on various parts of the body, for example, } \\
\text { finger scratching the palm of the hand, or (ii) object manipulators which were similar actions involving inani- } \\
\text { mate objects. }\end{array}$ \\
\hline Lower Extremities & This involved any movement occurring in the upper or lower leg/legs or the ankle. \\
\hline
\end{tabular}

ment of verbal or nonverbal behaviour" (Bales 1960, p. 37). For a movement to be considered for analysis, both raters had to have agreed as to its placement within a particular category.

The modified Iowa Scale (Johnson et al. 1963) and PersonalSocial Sensitivity Scales (Alant 1979) were then scored for each $S$ and were related to each other and to communicative competence.

\section{STATISTICÁL PROCEDURE}

The following non-parametric, descriptive statistical procedures used by Wiig (1982) to analyze verbal behaviour, were extended, for the present study, to nonverbal behaviour as well. Using the raw scores obtained by the group for each communicative function and context, a measure of central tendency (Mean), ranges of scores, rankings from highest/best scores to lowest/worst scores and predominant scores, were calculated. Inter-rater reliability for the verbal analysis was calculated as a percentage of agreement.

\section{RESULTS AND DISCUSSION}

Inter-rater reliability for the verbal analysis was found to be high $(88 \%)$.

\section{COMMUNICATION INVENTORY}

\section{a) Verbal analysis}

The results revealed that the subjects' verbal communicative abilities were on average ineffective. Paralinguistic incompetence was demonstrated in the features of rhythm, pitch, rate and pausing (Table 2).

As expected with stutterers, rhythm was shown to be generally uneven, although two subjects presented with rhythmical speech patterns as a fluency facilitator. Pitch was predominantly monotonous. The speech rate was judged to be slower than normal. Pausing prior to speech onset and hesitations during speech production were prevalent in two of the subjects.

Johnson et al. (1963) suggested that these factors may be due to the fact that the stutterer proceeds apprehensively and cau-
Table 2 Overall paralinguistic competence for all Ss' expressed as predominant scores, mean scores and rankings

\begin{tabular}{|l|c|c|c|}
\hline Feature & $\begin{array}{c}\text { Predominant } \\
\text { Score }\end{array}$ & Mean & Rank \\
\hline Rhythm & 2 & 1,7 & 7 \\
Pitch & 1 & 1,5 & 8 \\
Intonation & 3 & 2,8 & 4 \\
Intensity & 4 & 3,8 & 1 \\
Stress & 4 & 3,5 & 2 \\
Rate & 1 & 1,9 & 6 \\
Pausing & $2 / 3 / 4$ & 2,7 & 5 \\
Embolophrasia & 4 & 3,2 & 3 \\
\hline
\end{tabular}

\section{CODE}

$$
\begin{aligned}
& 4 \text { - good } \\
& 3 \text { - adequate } \\
& 2 \text { - fair } \\
& 1 \text { - poor }
\end{aligned}
$$

tiously as if looking for trouble. The feature of embolophrasia e.g. "er" and "um" and word repetitions was used as part of the stuttering symptomatology by two subjects. The other paralinguistic parameters were found to be largely unaffected by the stuttering. These results confirmed Bloodstein's statement in 1969, that what can be identified as stuttering, is not only evident in the fluency impairment, but also in certain paralinguistic parameters and that these features are not always confined to discrete moments.

Results of the morpheme count (as shown in Tables 3 and 4) revealed that the subjects used longer utterances when addressing adults, than when addressing peers. This is in accordance with what Wiig (1982) found with normal speakers. However, the subjects generally scored below the norms: They tended to use simple statements, with little elaboration. Dalton and Hardcastle (1977) described some stutterers, who cut down their utterances to the bare minimum, simplifying an argument to the point they felt they could make easily. One subject used extended utterances. However, this still rendered the commu- 
nication ineffective, mainly as a result of circumlocutions and rambling. The subjects in this study therefore did not appear to have learned the principle expounded by Wood (1981) that one must say just enough, but not too much.

Table 3 Morpheme analysis related to the two contexts

\begin{tabular}{|l|c|}
\hline Context & Mean \\
\hline Peer & 8,6 \\
Adult & 9,7 \\
\hline
\end{tabular}

Table 4 Morpheme analysis related to the four functions

\begin{tabular}{|c|c|c|}
\hline \multirow[b]{2}{*}{ CODE } & Function & \multirow{2}{*}{$\begin{array}{l}\text { Predominant } \\
\text { Score } \\
\downarrow \\
\downarrow\end{array}$} \\
\hline & $\begin{array}{l}\text { Ritualizing } \\
\text { Informing } \\
\text { Controlling } \\
\text { Feeling }\end{array}$ & \\
\hline A Abo & & \\
\hline
\end{tabular}

For verbal competence, both norm relations (Wiig 1982) and overall percentages were analysed on the communication inventory. In Table 5 it can be seen that, with respect to the contexts, the subjects performed most effectively in relation to the peer context.

Table 5 Verbal competence on inventory: stuttering frequency

\begin{tabular}{|l|c|}
\hline Context & $\%$ \\
\hline Peer & 79 \\
Adult & 60 \\
\hline
\end{tabular}

Table 6 Summary of the mean percentage and predominant scores for Ss' communicative competence on all four communication functions within both contexts

\begin{tabular}{|l|c|cc|}
\hline Function & Context & $\begin{array}{c}\text { Predominant } \\
\text { Score }\end{array}$ & $\%$ \\
\hline Ritualizing & Peer & $\vdots$ & 71 \\
& Adult & & 53 \\
Informing & Peer & & 83 \\
& Adult & $\vdots$ & 61 \\
Controlling & Peer & 78 \\
Feeling & Adult & Peer & 62 \\
& Adult & & 85 \\
\cline { 2 - 4 } & Ad & 62 \\
\hline
\end{tabular}

\footnotetext{
CODE

A Above norm

- Same as norm

below norm
}

Wiig (1982) pointed out that this was to be expected in relation to the norms. Thus, the stutterers tended to follow the normal trend of effectiveness, although when related to the normative data, they functioned below average for both peer and adult contexts. As can be seen from Table 5, the stuttering behaviour was shown to be considerably worse in the adult context.
In terms of the functions of communication (Table 6), the subjects performed least effectively on the ritualising function, in relation to both contexts.

The informing function revealed a considerably better performance in the peer context than in the adult context, although Wiig (1982) reported that both contexts should have been acquired.

The stuttering severity (Tables 7 and 8 ) appeared to be least severe in relation to the ritualising function and most severe in relation to the informing function.

Table 7 Stuttering analysis using predominant scores related to the four functions

\begin{tabular}{|l|c|}
\hline Function & $\begin{array}{c}\text { Predominant } \\
\text { Score }\end{array}$ \\
\hline Ritualizing & 0 \\
Informing & 3 \\
Controlling & 2 \\
Feoling & 1 \\
\hline
\end{tabular}

$$
\begin{aligned}
& \text { CODE } \\
& 0 \text { - no stuttering } \\
& 1-\text { mild stuttering } \\
& 2 \text { - moderate stuttering } \\
& 3 \text { - severe stuttering }
\end{aligned}
$$

Table 8 Stuttering analysis using predominant scores related to the two contexts

\begin{tabular}{|l|c|}
\hline Context & $\begin{array}{c}\text { Predominant } \\
\text { Score }\end{array}$ \\
\hline Peer & $0 ; 1$ \\
Adult & $2 ; 3$ \\
\hline
\end{tabular}

\section{CODE}

$$
\begin{aligned}
& 0 \text { - no stuttering } \\
& 1 \text { - mild stuttering } \\
& 2 \text { - moderate stuttering }
\end{aligned}
$$$$
3 \text { - severe stuttering }
$$

This may be related to the propositionality level associated with the different functions, since, as Eisenson (1975) pointed out, stuttering increases when meaningfulness increases. The controlling function revealed the poorest scores in relation to the norms of all four functions. This too, may be due to the higher propositionality of speech involved (Eisenson 1975). The subjects scored most effectively on the feeling function in terms of percentages and in relation to the normative data, yet they still scored below the norm. This may be related to the high personal sensitivity scores of the subjects revealing that they were possibly more in touch with their own feelings.

Thus the results indicated that the subjects did not perform according to the average standard described by Wiig (1982). Wiig suggested that this could be related to secondary emotional reactions interfering with the communication learning process.

\section{b) Nonverbal analysis}

The subjects did not use nonverbal communication to either enhance or detract from verbal communication, across pragmatic functions. This indicates a delay, as Wood (1981) stated that pre-adolescents should have basic pragmatic skills. Secon- 
dary stuttering did vary according to functions when related to propositionality. Thus infrequent stuttering was found for ritualising as this function contains little propositionality. An increase in both the amount and severity of secondary stuttering behaviours was found for the informing function as this implies propositionality. The most frequent amounts of stuttering were found for the controlling function, where propositionality is high. This function also requires skill which, according to Hopper and Naremore (1978), adults often do not acquire. Stuttering was decreased for the feeling function. This was possibly because this function was the last to be assessed and the subjects were more relaxed and familiar with the test situation.

Table 9 Summary of the comparison of scores of nonverbal stuttering (St) distracting (D) and complementing $(C)$ behaviours (Percentages were calculated relative to the frequency of occurrence of the functions)

\begin{tabular}{|l|c|c|c|c|c|c|}
\hline & St & $\%$ & D & $\%$ & C & $\%$ \\
\hline Head movements & 4 & 31 & 6 & 46 & 3 & 23 \\
Gaze & 4 & 22 & 6 & 33 & 8 & 44 \\
Facial expression & 5 & 50 & 3 & 30 & 2 & 20 \\
Posture & 4 & 31 & 6 & 46 & 3 & 23 \\
Gesture and illustrators & 3 & 50 & - & - & 3 & 50 \\
Shrug & - & - & - & - & 3 & 100 \\
Manipulators & 3 & 30 & 7 & 70 & - & - \\
Lower extremities & 2 & 8 & 9 & 82 & - & - \\
\hline
\end{tabular}

As illustrated in Table 9, limited effective communication occurred for head movements. Nodding was the only frequent complementing head movement observed, particularly during listening and speaking. This correlated with Knapp's (1978) statement that the head nod is probably the most familiar nonverbal act which maintains conversation. Distracting head movements and secondary stuttering behaviour also detracted from effective communication. Secondary stuttering head movements occurred during speaking as a release from a block as well as before stuttering as a starter. A close relationship between head movements and gaze was noted.

Eye contact is an important facet of face to face communication which occurs during listening and speaking, just before or after a thought unit is completed (Knapp 1978). Gaze acts were present on the complementing-checklists indicating adaptive eye contact. However maladaptive gaze patterns were also noted indicating evasion of social contact and interaction.

Facial expression is the second most commonly occurring stuttering symptom according to Bloodstein (1960). It was found in these subjects in the form of lip pursing before and during stuttering, resulting in ineffective communication.

High counts of shifting were present before and during speaking making posture one of the most distracting categories of nonverbal behaviours observed. Argyle (1977) states that posture is less well controlled than other nonverbal clues and is often an indicator of leakage, that is concealing information from the other interactor.

Gestures accompanying speech illustrate what is being said verbally (Knapp 1978). Generally the presence of illustrators was tentative and indicative of ineffective communication. A high percentage of restless or repetitive leg and foot acts formed part of the stuttering pattern. At other times these movements distracted from the communicative process.

In summary nonverbal behaviours were detracting from, rather than complementing verbal communication. Secondary stuttering exacerbated ineffective communication.

\section{ATTITUDES TO STUTTERING}

The subjects demonstrated an average mean score of attitudes to stuttering on the Iowa Scale. Nevertheless, the predominant scores revealed positive attitudes to stuttering. These positive attitudes did not correlate with the ineffective verbal and nonverbal communication parameters found. This may be a feature of pre-adolescence since the pre-adolescent stutterer has not yet experienced the accompanied social pressures and may therefore not have developed the negative attitudes so common in adults (Dalton and Hardcastle 1977).

\section{SENSITIVITY TO COMMUNICATION}

On the Personal Social Sensitivity Scale (Alant 1979), the subjects demonstrated high scores on the personal dimension and low scores on the social dimension. The high personal rating probably indicated that the subjects were involved in the encoding function and tended to be selfcentred and absorbed in their stuttering, without considering the other communicators or decoding function. The low social rating probably pointed to the fact that the subjects were not involved adequately in the interaction, revealing their incompetence in their communication and lack of awareness of others. This correlated with the ineffective interactive communication found in this study, and showed that the stutterers did not comply with the prerequisites for high social sensitivity described by Alant (1979).

\section{CONCLUSIONS}

The results of this study revealed that the Ss' communication abilities were on average ineffective. This led to ineffective communication and poor social interaction. Thus, speech therapy with stutterers of this age group should focus on both fluency and remediation of communication.

The ineffective conversation was demonstrated a) within all communication functions, particularly in the controlling function, and in relation to the adult context more than the peer context, b) in the shorter mean morpheme length and simple utterances used, with little elaboration, c) by certain paralinguistic features being of poor quality - uneven rhythm, monotonous pitch, slow rate, pausing before and during utterances, and poor intonation at times.

The paralinguistic incompetence could be directly related to the stuttering pattern, while the communicative incompetence in terms of intent and register, and morpheme length may also be related to the stuttering.

Behaviours complementing communication were present, but in limited amounts. Contrary to this, large and varied amounts of distracting nonverbal behaviours were found. These were exacerbated by the nonverbal stuttering actions, which constituted part of the communication problem. The nonverbal skills were not complementing verbal behaviour for pragmatic purposes. Pragmatic patterns émerged for secondary stuttering which seemed to relate stuttering to propositionality. 
Attitudes to stuttering were shown to be generally positive, which contradicts the hypothesis that poor communication results from poor attitudes. This may be related to the preadolescent age, when social pressure has been minimal. Therefore, it seems worthwhile to introduce therapy at this age, as this population seems to have a positive attitude towards communication that is uncharacteristic of older stutterers. However, the low interactive communication sensitivity and poor communication skills indicate that although the Ss' were intensely aware and sensitive to their own communication, they had low social sensitivity.

In conclusion it must be recognised that therapists must deal with much more than the speech of stutterers in order to give them "the tools needed to help them rejoin the human race" (Van Riper 1978, p. 6).

\section{REFERENCES}

Abercrombie, D. Paralanguage, Chapter 2, in Laver, J. and Hutcheson, S. (Eds.): Communication in Face to Face Interaction, Middlesex, Penguin books Ltd., 1968.

Alant, E. Speech and Language Pathology and Communication, Master of Arts, University of Pretoria, 1979.

Argyle, M. Bodily Communication, London, Methuen and Co. Ltd., 1975.

Argyle, M. Nonverbal communication in human social interaction, in Hinde, R.A. (Eds.): Nonverbal Communication, Great Britain, Cambridge University Press, 1977.

Barbara, P.A. Communication in stuttering, Chapter 22, in Emerick, L.L. and Hamre, C.E. (Eds.): An Analysis of Stuttering: Selected Readings, Illinois, The Interstate Printers and Publishers Inc., 1972.

Bloodstein, O. A Handbook on Stuttering, Chicago, National Easter Seal Society for Crippled Children and Adults, 1969.

Bloodstein, O. The Development of Stuttering I. Changes in Nine Basic Features, J. Speech Hearing Dis. 1960, 25, 219-237.

Cherry, C. On Human Communication: A review, a survey and a criticism, (3rd ed.), England, The MIT Press, 1978.

Dalton, P. and Hardcastle, E.J. Disorders of Fluency, London, Edward Arnold Ltd., 1977.

Eisenson, J. Stuttering as a perseverative behaviour. Chapter
VI, in, Eisenson, J. (Ed.): Stuttering: A Second Symposi$u m$, New York, Harper and Row Publishers, 1975.

Erickson, R.L. Assessing communication attitudes amongst stutterers, J. Speech Hear. Res. 1969, 12, 711-724.

Hopper, R. and Naremore, R.J. Children's Speech - A Practical Introduction to Communication Development, Second Edition, New York, Harper and Row Publishers Inc., 1978.

Johnson, W., Darley, F.L. and Spriestersbach, D.L. Diagnostic Methods in Speech Pathology, New York, 1963.

Knapp, M.L. Nonverbal Communication in Human Interaction, Second Edition, New York, Holt, Rinehart and Winston, 1978.

Luper, H.L. and Mulder, R.L. Stuttering: Therapy for Children, Englewood Cliffs, New Jersey, Prentice Hall Inc., 1964.

Muma, J.P. Language Handbook Concepts, Assessment, Intervention, Englewood Cliffs, New Jersey, Prentice Hall Inc., 1978.

Myers, G.E. and Myers, M.T. The dynamics of human communication: A laboratory approach. (Second edition), McGraw-Hill Book Company, 1976.

Saling, M. Personal Communication, Senior Lecturer, Dept. of Psychology, University of the Witwatersrand, Johannesburg, 1983.

Shames, G.H. and Florance, C.L. Stutter-Free Speech: A goal for therapy, Columbus, Ohio, Charles E. Merrill Publishing Co., 1980.

Sheehan, J. Stuttering as a self-role conflict. Chapter V, in, Gregory, H.H. (Ed.): Learning Theory and Stuttering Therapy, Evanston, Northwestern University Press, 1968.

Shuter, R. Understanding Misunderstandings, Exploring Interpersonal Communication, New York, Harper and Row, 1979.

Van Riper, C. Speech Correction: Principles and Methods, Sixth Edition, Englewood Cliffs, New Jersey, Prentice Hall Inc., 1978.

Wiig, E.H. Let's Talk Inventory for Adolescents, Manual, Columbus Ohio, Charles E. Merrill Publishing Company, 1982.

Wiig, E.H. and Semel, E.M. Language Disabilities in Children and Adolescents, Columbus, Ohio, Charles E. Merrill Publishing Company, 1976.

Wood, B. Children and Communication, Second Edition, Englewood Cliffs, New Jersey, Prentice Hall Inc., 1981. 


\title{
SIEMENS - Quality
}

\section{Hearing Aids \\ and}

School Teaching Equipment

from

\section{REPUBuC consultants GTYLTD}

\author{
New Address: \\ 187 JAN SMUTS AVENUE \\ LOWER ROSEBANK \\ (Opposite Thrupps) \\ TELEPHONE: 442-8691
}

